\title{
PERBEDAAN ANTARA PENGGUNAAN FOCUS GROUP DISCUSSION (FGD) DENGAN PROSES GROUND, UNDERSTAND, REVISE, AND USE (GURU) TERHADAP EFIKASI DIRI KARIER MAHASISWA S1 BIMBINGAN DAN KONSELING
}

\author{
Yuanita Dwi Krisphianti ${ }^{1}$, Nora Yuniar Setyaputri², Ikke Yuliani Dhian Puspitarini ${ }^{3}$ \\ Universitas Nusantara PGRI Kediri'1,2,3 \\ ju.wahyu@gmail.com ${ }^{1}$, setyaputrinora@gmail.com ${ }^{2}, \underline{\text { ikkeyulianidp@gmail.com }}^{3}$
}

\section{ABSTRAK}

Efikasi diri karier merupakan keyakinan akan kemampuan dalam melakukan suatu usaha untuk mendapatkan keinginan dan menjadi berhasil di masa yang akan datang. Efikasi diri karier sudah semestinya dimiliki oleh mahasiswa program studi Bimbingan dan Konseling Universitas Nusantara PGRI (BK UNP) Kediri. Akan tetapi, fakta di lapangan ternyata hal ini menjadi problematik. Alternatif untuk meningkatkan efikasi diri karier mereka digunakan dua teknik yakni FGD dan Proses GURU. Tujuan dari penelitian ini adalah untuk mendapatkan data tentang perbedaan penggunaan FGD dengan Proses GURU terhadap efikasi diri karier mahasiswa S1 BK UNP Kediri. Penelitian ini menggunakan pendekatan kuantitatif dengan desain preposttest two treatment design . Populasi yang digunakan adalah mahasiswa tingkat 4 angkatan 2016/2017 sedangkan sampel yang digunakan 12 mahasiswa tingkat 4 angkatan 2016/2017. Pengumpula data dalam penelitian menggunaka skala efikasi diri karier. Analisa data menggunakan uji Man-Whitney dengan hasil sig 0,687 $\geq$ 0,05 , yang berarti Ho diterima. Berdasarkan hasil analisa data maka kesimpulan yang bisa diambil adalah tidak ada perbedaan antara penggunaan FGD dengan Proses GURU terhadap efikasi diri karier mahasiswa S1 BK UNP Kediri. Saran yang bisa diberikan, (1) dua teknik ini bisa menjadi alternatif bagi dosen BK untuk meningkatkan efikasi diri karier mahasiswa, (2) peneliti selanjutnya bisa menggunakan dua teknik ini dalam meningkatkan variabel penelitian yang lain.
\end{abstract}

Kata Kunci efikasi diri karier, FGD, proses GURU

Cara mengutip: Krisphianti, Y. D., Setyaputri, N.Y. \& Puspitarini, I. Y. D. (2019) Perbedaan Antara Penggunaan Focus Group Discussion (FGD) dengan Proses Ground, Understand, Revise, and Use (Guru) Terhadap Efikasi Diri Karier Mahasiswa S1 Bimbingan dan Konseling. Nusantara of Research, 6(1), 33-40.

\section{PENDAHULUAN}

Efikasi diri merupakan keyakinan yang tumbuh dalam diri individu untuk melakukan suatu usaha dalam menggapai keinginannya, hingga usaha tersebut berdampak positif terhadap keinginan yang dicitakan (Bandura, 1994). Efikasi diri yang muncul dalam diri individu berasal dari (a) proses keaktifan yakni meregulasi emosi dan reaksi emosi atas suatu peristiwa, (b) proses kognitif yakni proses berfikir untuk mengakuisisi, mengorganisir, dan menggunakan suatu informasi, (c) motivasi yakni timbulnya dorongan dari dalam dan luar untuk melakukan suatu usaha, dan (d) regulasi diri yakni mengendalikan pikiran, motivasi, dan perilaku untuk suatu usaha mencapai kesuksesan. Efikasi diri adalah penting berkontribusi pada suatu kompetensi dan kesuksesan dari seorang individu.

Proses efikasi diri sangatlah penting untuk tumbuh dalam setiap individu. Karena dengan efikasi diri mereka akan mampu memiliki keyakinan untuk sukses dalam kehidupan mereka. Kesuksesan tersebut salah satunya dipandang dari segi pendidikan. Seorang siswa 
dituntut untuk memiliki efikasi diri, dalam hal ini dikenal dengan istilah efikasi diri karier. Efikasi diri karier merupakan keyakinan individu atas kemampuan diriya untuk melakukaan suatu usaha hingga mendapatkan sebuah keberhasilan kariernya ke depan depan (Feehan \& Johnston (1999); Anderson \& Betz (2001) dan Lenz \& Hackett (1987); Brusokas \& Malinauskas (2014) dalam Setyaputri, dkk (2017).

Efikasi diri karier ini hendaknya juga dimilliki oleh mahasiswa S1 Bimbingan dan Konseling Universitas Nusantara PGRI Kediri. Akan tetapi kenyataan di lapangan ditemukan fakta yang berbeda. Observasi di lapangan yang melibatkan mahasiswa tingkat 4 angkatan 2016/2017, telah ditemukan beberapa problematik di lapangan yang terkait hal ini yaitu mahasiswa S1 BK UNP masuk prodi ini hanya karena ikut-ikutan teman, mahasiswa masuk prodi hanya karena suruhan dari orangtua, dan mahasiswa masuk prodi BK hanya karena yang penting kuliah. Problematik ini timbul ketika mereka selesai melaksanakan magang 1 di sekolah, sehingga berakibat tidak tahu apa yang harus di lakukan ketika sudah proses magang 1. Padahal seharusnya, mahasiswa sudah memiliki bekal pada proses perkuliahan sebelum magang. Hal ini jika tidak segera mendapatkan penanganan akan berdampak pada kualitas dari guru BK ketika mereka nanti lulus kuliah dan menjadi seorang guru BK. Selain itu, akan menjadi sebuah boomerang bagi mereka karena tidak dapat bersaing dengan lulusan BK dari lembaga pendidikan tenaga kependidikan (LPTK) yang lain.

Alternatif yang digunakan untuk menangani masalah yang terkait adalah dengan menggunakan teknik Focus Group Discussion (FGD) dan Proses Ground Understand Revise Use (GURU). FGD merupakan sebuah teknik diskusi dengan topik pengalaman atau hal baru yang terjadi dalam diri individu. FGD sebuah teknik yag dapat digunakan untuk membantu individu menumbuhkan keyakinan dalam dirinya senada dengan penelitian Istanti (2013) FGD efektif digunakan untuk meningkatkan karakter tanggung jawab siswa terhadap prestasi akademiknya, juga penelitian Krisphianti (2015) FGD efektif digunakan untuk meningkatkan karakter fairness pada diri siswa. Selain itu Gonzales (2009) bahwa FGD dapat digunakan unruk mendukung keberhasilan akademik siswa dengan cara bersikap terbuka ketika melakukan musyarawarah atau diskusi, saling memberikan saran agar dapat meningkatkan prestasi akademiknya.

Dari ketiga penelitian tersebut memang tidak secara langsung disebutkan bahwa FGD dapat digunakan untuk meningkatkan efikasi diri karier mahasiswa, akan tetapi dari penelitian tersebut dapat diambil kesimpulan bahwa melalui proses FGD mahasiswa mampu belajar untuk bertukar pikiran, bersikap terbuka untuk mendiskusikan suatu masalah yang sudah dialami maupun yang belum dialami dan mahasiswa bisa saling memberikan saran agar dapat menumbuhkan efikasi diri karier dalam diri mereka. Karakteristik pelaksanaan FGD terletak pada penggunaan wawancara semi struktur kepada suatu kelompok individu dengan seorang moderator yang memimpin diskusi dengan tatanan informal dan bertujuan mengumpulkan data atau informasi tentang topik isu tertentu (Carey, 1994).

Selain FGD, alternatif teknik yang digunakan untuk meningkatkan efikasi diri karier mahasiswa S1 BK UNP Kediri adalah dengan menggunakan Proses GURU. Proses GURU merupakan bagian dari model praktik reflektif, sebuah proses yang masuk dalam experiential learning. Experiential learning merupakan metode pembelajaran yang didasarkan pada pengalaman individu. Remer (dalam Silberman, 2007), Proses GURU merupakan kombinasi dari merefleksikan peristiwa yang terjadi dengan peristiwa lainnya dengan memunculkan pertanyaan-pertanyaan dalam diri. Proses ini menyatakan bahwa menimbulkan pertanyaan dalam diri yang terkait dengan peristiwa merupakan cara belajar yang lebih mudah didalam putaran experiential learning. 
Pada Proses GURU individu dapat memberikan pertanyaan yang membantu dalam menganalisa situasi, membuat sebuah kesimpulan, merencanakan suatu hal, dan mengimplementasikan langkah pertama dari rencana yang telah dibuat. GURU merupakan akronim dari kategori pertanyaan yakni Ground $(G)$, Understand $(U)$, Revise $(R)$, Use (U). Individu dapat memposisikan dirinya sebagai pembelajar, supervisor, mentor, pelatih, bahkan diri sendiri ketika menerapkan masing-masing kategori pertanyaan tersebut dalam sebuah proses yang dilakukan.

Adapun penjelasan dari setiap kategori pertanyaan dari GURU adalah sebagai berikut; (a) Ground artinya pertanyaan yang membantu individu mengingat peristiwa dan mengingat kembali basic data dari pengalaman yang telah dialami; (b) Understanding artinya kategori pertanyaan yang digunakan untuk membantu individu dalam memahami situasi dengan konteks yang lebih luas. Pertanyaan ini harus mendorong individu dalam mengidentifikasi kemiripan dan perbedaan yang terjadi antara peristiwa, ide, dan atau perilaku. Pertanyaan ini juga mendorong individu untuk memahami apa yang mereka pelajari dan kesimpulan apa yang telah mereka buat; (c) Revise artinya kategori pertanyaan yang membantu individu untuk kemungkinan memodifikasi perilaku atau sikap mereka; dan (d) Use artinya kategori pertanyaan harus membantu individu untuk dapat memikirkan apa yang mereka inginkan setelah mendapatkan informasi dan ide dari yang sudah dipelajari (Remer, dalam Silberman 2007).

Dari pemaparan di atas disimpulkan bahwa Proses GURU merupakan metode pembelajaran yang menggunakan pengalaman pribadi sebagai cara untuk menemukan suatu pemahaman yang baru. Proses GURU sebelumnya juga pernah digunakan pada penelitian sebelumnya oleh Setyaputri, dkk (2017) yaitu Proses GURU efektif digunakan untuk meningkatkan efikasi diri karier mahasiswa S1 BK UNP Kediri tingkat IV angkatan 2013.

\section{METODE}

Pada penelitian ini digunakan pendekatan penelitian kuantitatif dengan desain penelitian experiment yang digunakan adalah the pretest-post-test two treatment designs. Desain ini dipilih didasarkan pada (a) desain yang tepat untuk menguji hipotesis yakni membandingkan pengaruh antara dua treatment yang berbeda, dan (b) desain pada dasarnya digunakan untuk mengetahui perbedaan kelompok dengan cirri khas yang dimiliki (Creswell, 2012). Ciri khas utama dalam desain ini adalah pemberian pre-post test pada subjek penelitian. Pemberian pretest dilakukan sebelum kedua kelomok diberikan treatment dan pemberian posttest diberikan setelah kedua kelompok melaksanakan treatment. Adapun desain ekspreimen dapat dilihat lebih jelas pada gambar 1 sebagai berikut.

$\begin{array}{llll}\text { Experimental } & \mathrm{RO}_{1} & \mathrm{X}_{1} & \mathrm{O}_{2} \\ \text { Experimental } & \mathrm{RO}_{3} & \mathrm{X}_{2} & \mathrm{O}_{4}\end{array}$

Gambar 1.1. The pre-postets two treatment design

Sumber: Cohen, Manion\&Morrison, 2007

$\mathrm{R}$

:Pemilihan subjek secara random

$\mathrm{O}_{1} \quad$ : Pretest kelompok eksperimen I sebelum diberikan treatment

$\mathrm{X}_{1} \quad$ : Treatment/perlakuan teknik storytelling lakon Panji

$\mathrm{O}_{2} \quad$ : Posttest kelompok eksperimen I setelah diberikan treatment

$\mathrm{O}_{3} \quad$ : Pretest kelompok eksperimen II sebelum diberikan treatment

$\mathrm{X}_{2} \quad$ : Treatment/perlakuan metode FGD

$\mathrm{O}_{4} \quad$ : Posttest kelompok eksperimen II setelah diberikan treatment 
Berdasarkan gambar desain penelitian di atas dapat dijelaskan bahwa terdapat dua kelompok, yakni kelompok eksperimen 1 dan kelompok eksperimen 2. Pemilihan anggota kelompok 1 dan 2 dipilih secara random setelah sebelumnya dilakukan observasi dan wawancara tentang self esikasi diri karier mereka. Setelah dilakukan pemilihan maka dilakukan pengukuran menggunakan skala efikasi diri karier, jadi bisa dipastikan bahwa anggota kelompok semua memiliki nilai efikasi diri karier yang rendah. Kemudian pemberian treatment FGD kepada kelompok 1 dan pemberian treatment Proses GURU kepada kelompok 2. Setelah diberikan treatment pada kedua kelompok kemudian dilakukan post test kepada kedua kelompok dengan menggunakan skala efikasi diri karier.

Populasi yang dalam penelitian adalah mahasiswa S1 prodi BK UNP Kediri tingkat IV tahun angkatan 2016, dimana mereka telah selesai menyelesaikan magang 1 di sekolah. Subjek penelitian yang digunakan adalah 12 mahasiswa yang memiliki ciri khas dengan efikasi diri karier yang rendah. Setiap anggota kelompok terdiri dari enam mahasiswa, hal ini didasarkan pada jumlah anggota kelompok yang efektif pada FGD adalah 5 sampai 10 individu akan tetapi lebih disarankan 6 sampai 8 individu (Kruenger, 2002).

Pengumpulan data menggunakan skala efikasi diri karier. Analisis data menggunakan uji man-whitney, hal ini memiliki tujuan membandingkan dua buah sampel yang berasal dari populasi yang sama dan melihat perbedaan signifikan penggunaan FGD dan Proses GURU terhadap efikasi diri karier mahasiswa S1 BK UNP Kediri. Hipotesis dari penelitian ini adalah terdapat perbedaan antara penggunaan teknik FGD dengan Proses GURU terhadap efikasi diri karier mahasiswa S1 BK UNP Kediri. Pengujian hipotesis yang digunakan sebagai dasar pengambilan keputusan dengan melihat angka probabilitas error. Ketentuan untuk menolak/tidak $H_{0}$ berdasarkan probabilitas error $(\alpha=0.05)$, yakni jika probabilitas $\geq a$ maka $\mathrm{H}_{\mathrm{o}}$ diterima dan sebaliknya jika probabilitas $\leq \mathrm{a}$ maka $\mathrm{H}_{0}$ ditolak. Untuk probabilitas pada program SPSS digunakan istilah significance (sig) (Santoso, 2012).

HASIL

Penelitian kuantitatif ini menghasilkan sebuah data tentang perbedaan penggunaan teknik FGD dan Proses GURU terhadap efikasi diri karier mahasiswa S1 BK UNP tingkat IV angkatan 2016. Sebelum dijabarkan tentang analisis data, maka akan dipaparkan hasil dari prepost test dari kedua kelompok pada tabel 1 , sebagai berikut.

Tabel 1.1. Data Pre-Post Test FGD

\begin{tabular}{cccccc} 
No & Identitas & Pre Test FGD & Kategori & Post test FGD & Kategori \\
\hline 1 & SP & 34 & Rendah & 59 & Tinggi \\
\hline 2 & DN & 43 & Rendah & 59 & Tinggi \\
\hline 3 & YN & 44 & Rendah & 60 & Tinggi \\
\hline 4 & SL & 30 & Rendah & 63 & Sangat Tinggi \\
\hline 5 & HN & 41 & Rendah & 63 & Sangat Tinggi \\
\hline 6 & BK & 44 & Rendah & 53 & Tinggi
\end{tabular}

Tabel 1.2. Data Pre-Post Proses GURU

\begin{tabular}{cccccc} 
No & Identitas & Pre Test GURU & Kategori & Post test GURU & Kategori \\
\hline 1 & FN & 44 & Rendah & 48 & Tinggi \\
\hline 2 & EO & 31 & Rendah & 67 & Sangat Tinggi \\
\hline 3 & RG & 28 & Rendah & 68 & Sangat Tinggi \\
\hline 4 & LS & 36 & Rendah & 60 & Tinggi \\
\hline 5 & WY & 27 & Rendah & 62 & Tinggi \\
\hline 6 & AN & 30 & Rendah & 56 & Tinggi
\end{tabular}




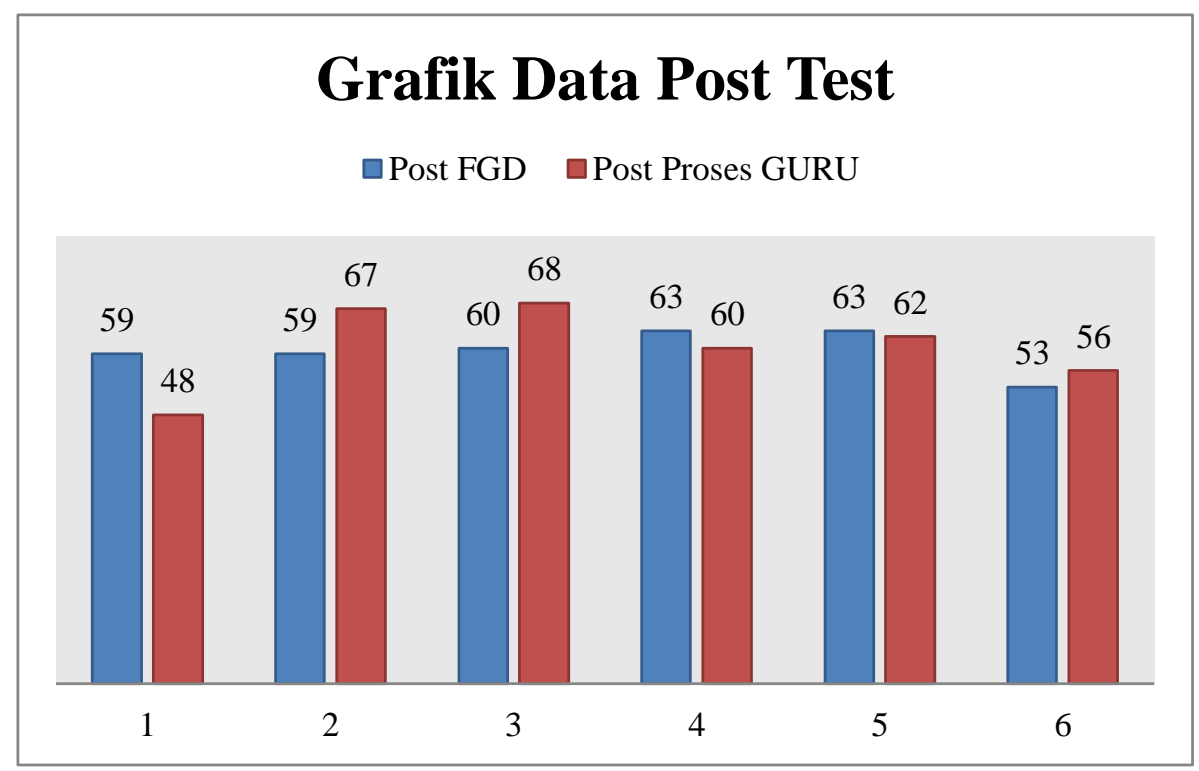

Gambar 1.2. Grafik Data post test penelitian

Berdasarkan tabel 1 dan grafik $1 \mathrm{di}$ atas, bisa dilihat bahwa nilai pretest kelompok FGD dan kelompok Proses GURU memiliki nilai dengan kategori rendah semuanya. Setelah dilakukan treatment pada dua kelompok, maka menghasilkan nilai posttest dengan kategori tinggi dan sangat tinggi. Adapun hasil dari analisa data dapat dilihat pada tabel 2 di bawah ini.

Tabel 1.3. Hasil analisa data Mann-Whitney

Test Statistics ${ }^{a}$

NILAI POST TEST

\begin{tabular}{lr}
\hline Mann-Whitney U & 15.500 \\
\hline Wilcoxon W & 36.500 \\
\hline Z & -.402 \\
\hline Asymp. Sig. (2-tailed) & .687 \\
\hline Exact Sig. [2*(1-tailed Sig.)] & $.699 \mathrm{~b}$
\end{tabular}

a. Grouping Variable: KELOMPOK

b. Not corrected for ties.

Berdasarkan data di atas bisa dilihat bahwa nilai sig. 0,687 $\geq 0,05$. Berdasarkan hasil analisa data maka hasil dari penelitian dinyatakan hipotesis tidak diterima atau tidak terdapat perbedaan antara penggunaan teknik FGD dengan Proses GURU terhadap efikasi diri karier mahasiswa S1 BK UNP Kediri.

\section{PEMBAHASAN}

Berdasarkan hasil uji analisa data yang menggunakan uji man whitney didapat nilai sig 0,687 . Nilai sig $0,687 \geq 0,05$, hal ini memiliki arti bahwa tidak ada perbedaan penggunaan teknik FGD dengan Proses GURU terhadap efikasi diri karier mahasiswa S1 BK Universitas Nusantara PGRI Kediri. Kedua teknik dapat digunakan untuk meningkatkan efikasi diri karier mahasiswa S1 Bimbingan dan Konseling UNP Kediri.

Focuss Group Discussion (FGD) memang merupakan sebuah teknik yang dapat digunakan dalam pendekatan penelitian kuantitatif dan kualitatif. FGD juga merupakan teknik diskusi kelompok yang pelaksanaannya terarah (Morgan, 1988). Pendapat lain mengatakan 
bahwa FGD merupakan proses kelompok yang dibentuk untuk mengumpulkan data sebagai tujuan penelitian tanpa merugikan lingkungan sekitar (Kruenger\&Casey, 2009). Selain itu, FGD sangat membantu anggota kelompok dalam mendiskusikan sebuah persepsi, ide, pendapat, dan pikiran mereka (Kruenger\&Casey, 2000; Zoran, dkk, 2009). Dengan kata lain, FGD merupakan teknik relevan untuk digunakan dalam pendekatan penelitian kuantitatif dan kualitatif.

Melalui proses FGD mahasiswa S1 Bimbingan dan Konseling dengan efikasi diri karier rendah akan mampu belajar untuk saling bertukar pikiran, bersikap terbuka untuk mendiskusikan suatu masalah yang sudah dialami maupun yang belum dialami. Salah satu keunggulan dari FGD adalah karakteristik yang dimiliki. Karakteristik pelaksanaan FGD terletak pada proses diskusi yang menggunakan wawancara semi struktur kepada suatu kelompok, disertai moderator yang memimpin diskusi hingga menemukan data atau informasi tertentu yang dibahas.

Perkembangan FGD di Indonesia mulai dikenal sebagai terapi kelompok yang telah dimodifikasi sesuai dengan kebutuhan dan dapat digunakan untuk mengungkapkan motivasi yang mendasari tingkah laku (Prawitasari, 1993 dalam Lohmay, 1998). Selain itu, ada penelitian lain yang dilakukan oleh Lohmay (1998) bahwa FGD efektif digunakan sebagai teknik pengubahan perilaku irasional dalam kegiatan akademik, dimana penerapannya dilakukan pengadaptasian FGD dalam REBT. Adanya teori dan penelitian terdahulu menjadi pendukung bahwa FGD dapat digunakan untuk meningkatkan efikasi diri karier mahasiswa S1 BK UNP Kediri.

Proses GURU yang merupakan bagian dari experiential learning merupakan teknik yang efektif digunakan sebagai salah satu alternatif meningkatkan efikasi diri karier mahasiswa S1 BK yang rendah. Pelaksanaannya Proses GURU tidak membutuhkan waktu yang panjang dan prosesnya cenderung mudah. Hal ini karena dalam Proses GURU menggunakan pertanyaan-pertanyaan yang memancing individu dalam memahami pengalamannya. Seperti pada hasil penelitian yang telah dilakukan Hanggara (2016) yang berjudul keefektifan "Proses GURU" sebagai Teknik Bimbingan Kelompok dalam Meningkatkan Kemampuan Pengambilan Keputusan Karier Siswa SMK, dimana hasil penelitian membuktikan bahwa dengan menggunakan Proses GURU kemampuan pengambilan keputusan karier siswa SMK dapat ditingkatkan.

Proses GURU juga merupakan sebuah bentuk dari praktik reflektif yakni proses yang pelaksanaanya mengutamakan pengalaman tertentu yang telah dialami oleh individu dan merefleksikan pengalaman tersebut untuk memperoleh suatu perilaku baru yang lebih efektif dan produktif. Remer (Silberman, 2007) menyimpulkan bahwa dengan menggunakan Proses GURU individu akan memiliki keuntungan tersendiri, diantaranya (a) individu memiliki pertimbangan dan mampu menentukan perilaku apa yang akan dilakukan ketika menghadapi suatu peristiwa, (b) individu mampu mengkontrol emosi, (c) individu mampu beradaptsai cepat dengan lingkungan baru, (d) individu bisa mengalami pengubahan pola piker yang jauh lebih efektif, (e) individu mampu lebih cermat dalam menghadapi suatu peristiiwa, $(f)$ individu mampu melakukan evaluasi terhadap apa yang telah dilakukan, dan (g) individu mampu merencanakan perilaku apa yang akan dilakukan pada peristiwa selanjutnya yang dihadapi.

Berdasarkan penjelasan di atas dapat diketahui teknik FGD dan Proses GURU dapat digunakan untuk meningkatkan efikasi diri karier mahasiswa S1 BK UNP Kediri angkatan tahun 2016. Hal ini didukung dengan hasil analisa data yang menunjukkan nilai sig 0,687. Hal ini memiliki arti bahwa sig $0,687 \geq 0,05$ maka Ho diterima yakni tidak ada perbedaan penggunaan 
teknik FGD dengan Proses GURU terhadapa efikasi diri karier mahasiswa S1 BK UNP Kediri. hasil ini juga mendukung bahwa Paket Pelatihan "GURU-Karier" ampuh untuk meningkatkan efikasi diri karier calon konselor sebuah penelitian yang telah dilakukan oleh Setyaputri (2016).

\section{KESIMPULAN DAN SARAN}

Pada penelitian ini didapat hasil analisa data sig $0,687 \geq 0,05$. Hal ini memiliki arti bahwa tidak terdapat perbedaan penggunaan teknik FGD dengan Proses GURU terhadap efikasi diri karier mahasiswa S1 Bimbingan dan Konseling Universitas Nusantara PGRI Kediri. Adapun saran yang bisa diberikan dari penelitian ini adalah bagi dosen BK memiliki pilihan alternatif dalam membantu meningkatkan efikasi diri karier mahasiswa S1. Bagi peneliti selanjutnya bisa menerapkan teknik FGD dan Proses GURU pada jumlah subjek yang lebih luas. Selan itu, bagi peneliti selanjutnya bisa menggunakan teknik FGD atau Proses GURU untuk diterapkan pada variabel-variabel penelitian yang lain.

\section{DAFTAR RUJUKAN}

Bandura, A. 1994.Self Efficacy.Encyclopedia of Human Behavior, Vol 4: 71-81.

Carey, M.A. (1994). The Group Effect in Focus Groups: Planning, Implementing, and Interpreting Focus Group Research. In Critical Issues in Qualitative Research Methods (Morse J.M., ed.). Sage: Thousand Oaks, 225-241.

Cohen, L. Manion, L \& Morrison, K. 2007. Research Methods in Education Sixth edition. New York: Routledge Taylor \& Francis Group. (Online), http://www. knowledgeportal.pakteachers.org/.../RESEARCH\%2OMETHOD\%20COH, diakses 24 Juni 2015.

Creswell, John W. 2012. Education Research Planning, Conducting, and Evaluating Quantitative and Qualitative Research Four Edition. United States of Amerika: Pearson Education.

Hanggara, G.S. 2016.Keefektifan "Proses Guru" Sebagai Teknik Bimbingan Kelompok Dalam Meningkatkan Pengambilan Keputusan Karier Siswa SMK.Tesis. Malang: Program Pasca Sarjana. Universitas Negeri Malang.Jurusan Bimbingan dan Konseling.

Holmes, G. E. 1994. Integrating Focus Group Research and Group Counseling. Education Resources Information Center.(Online), (http://www.ehow.com/info 8362338 definition-focus-groups-counseling.html), diakses 2 januari 2015.

Krisphianti, Y.D. 2015. Perbandingan Teknik Storytelling Menggunakan Media Wayang Topeng Malang dan Metode Focus Group Discussion Untuk Meningkatkan Karakter Fairness Siswa Sekolah Dasar. Tesis tidak diterbitkan. Malang: Universitas Negeri Malang.

Krueger, R. A., \& Casey, M. A. 2009. Conducting Focus Groups with College Students: Strategies to Ensure Success Association for International Reseacrh (AIR). Professional File, Number 127.

Krueger, Richard.A. 2002. Designing and Conducting Focus Group Interview. St.Paul: University of Minnesota. (Online), (kruenger@umn.edu), diakses tanggal 23 Januari 2015.

Lohmay, I. 1998. Pengubahan Perilaku Irasional Dalam Kegiatan Akademik Melalui Diskusi Kelompok Terarah. Tesis tidak diterbitkan. Malang: Pascasarjana UM 
Morgan, L. David. 1988. Focus Groups As Qualitative Research. California: A Sage University Paper.

Santoso Singgih. 2012. Aplikasi SPSS pada Statistik Non Parametrik. Jakarta: PT. Elek Media Komputindo

Setyaputri, N.Y., Lasan, B.B., \& Permatasari, D.2016.Pengembangan Paket pelatihan "Ground, Understand, Revise, Use (GURU)-Karier" untuk Meningkatkan Efikasi Diri Karier Calon Konselor. Jurnal Kajian Bimbingan dan Konseling, Vol. 1(4): 132-141

Setyaputri. Krisphianti. Puspitarini. 2017. Peningkatan Efikasi Diri Karier Mahasiswa S1 Bimbingan dan Konseling UN PGRI Kediri Melalui Paket Pelatihan GURU-Karier. Jurnal Nusantara of Research Vol 4. No 2, hal 93-99. UNP Kediri

Silberman, M. 2007. The Handbook of Experiential Learning. San Fransisco: John Wiley \& Sons. Inc. 